\title{
Land Holders and Fire Insurance: Case of Lagos Nigeria 2013
}

\author{
Barrister (Mrs.) Nneoma Iroaganachi \\ ${ }^{*}$ Mr. Joseph Kalu Ufere \\ Estate Management Programme, \\ A. T. B. University, Bauchi, Bauchi State, Nigeria \\ *Email: khalujosef@gmail.com \\ Email: chiomaobinna@yahoo.com
}

\section{Doi:10.5901/mjss.2013.v4n6p91}

\section{Abstract}

Land is a commodity whose ownership maintenance and protection is essential and indispensable to the development of every modern society as ours. Land holders therefore have a duty to maintain and protect same from risks including the fury of fire. Fire insurance protects against damage to land or building as a result of fire outbreaks resulting from riots, electrical malfunctions, arson and natural disaster etcetera. The work canvassed fire insurance as a viable method for the protection and mitigation of effects of fire outbreaks on Land. The work observed the present unpopularity of fire insurance practice among landholders and the fact that insurers and their agents are yet to earn the trust of Landholders by improving their performance and effectiveness in the area under research. Questionnaires were administered to randomly sampled Landholders in the 20 main Local Government Areas of Lagos state, Nigeria, while interviews were also conducted. It was the finding of the work that although in its present state, the fire insurance scheme or business seem to be in a tutelage stage, that it however has the potential of being greatly improved by a joint action of the government and other stakeholders, to serve as an effective and viable risk bearer for landholders not just located in Lagos but indeed all over the Nigerian State.

\section{Introduction}

Land is and has been an important commodity in every nation, Landholders ability to manage and protect their use and enjoyment of land contributes in no small measure to land development and Nation buildings. Several risks are associated with landholding in Nigeria, but the menace and fury of fire seem greater and must be given proper attention through the employment of an effective fire insurance system.

The said fury of fire is a risk that landholders should not ignore or underestimate as the possibility of the hazard to cause severe emotional, financial and other losses is great. By taking out an insurance policy, a landholder attempts to protect himself from risks. Irukwu (1971) opined that the purpose of insurance is to compensate or indemnify the victim or insured for the financial loss suffered as a result of the risk covered by the particular insurance policy. The insurance company therefore becomes the risk bearer and in the event of loss, pays the insured certain monies aimed at cushioning the effect of the loss or acting as an outright indemnity.

The Osborne's Law Dictionary (2009) defined insurance as a contract whereby a person called the insurer or assurer, agrees in consideration of money paid to him, called the insured or assured, to indemnify the later against loss resulting to him on the happening of certain events. The policy is the document that contains the terms of the contract.

The exact origin of insurance is shrouded in deep controversy and some historians are of the opinion that insurance have existed for over one thousand (1000) years. Irukwu (1971) further adumbrated that there is little literature on the subject of insurance in Africa, but that there is abundant evidence to show that although insurance has been in existence in Europe for over 700 years, in its modern sense, it is unknown to most Black Africa until it was introduced by the early British Merchants Patterned along British lines. The above notwithstanding, the case of Nigeria is slightly different as the practice of insurance had always been informally and crudely known by the indigenous society dating back to time immemorial. For an instance, in the Eastern part of the country, the Age-grade, Umuada, Umunna and the extended family systems respectively function as a social insurance system. It is however sad to note that in spite of this informed social insurance scheme and the fact of Nigerian's independences since 1960, insurance law as it is known today in practice is still barely at a tutelage stage. The citizenry are yet to embrace insurance as a risk mitigating factor. Most still ignorantly hold tenaciously to the aforementioned social insurance scheme as practiced by 
their forefathers. Unfortunately, as they ignore the opportunity and privilege of modern insurance practices, they suffer untold hardship in the event of disasters as the achaic social scheme is not designed to cater for the ever evolving and complex risks associates with daily living.

As an institution, insurance companies actively contribute to the development of the economy by providing stability for the individuals, groups and juridical persons who take out insurance policies while the accumulated funds are pumped back into the economy. The above notwithstanding, where the insurance industry is redundant and their services not solicited, the economy will be worse off for it and the natural and juridical persons would most likely bear needless pains such that could have been avoided or ameliorated by the privilege of insurance.

The insurance Act of 1990 (now 2004) is described as an Act to make provisions for the better management and regulation of insurance business in Nigeria and to make provisions in respect of disclosure of facts, warranty and conditions, insurable interest, assignment of policy, application of moneys, rights of parties and other related matters. Its second section classified insurance business in Nigeria into two main parts and provides that; "For the purposes of this Act, insurance business shall be divided into two main classes, 2(1) business; and (b) Non-life insurance business"

(a) Life insurance

The non-life insurance businesses are sub-divided by section 2(2) into the following categories;

"(a) Fire insurance business;

(b) Accident insurance business;

(c) Motor vehicle insurance business;

(d) Workmen's compensation insurance business;

(e) Marine, aviation and transport insurance business; and

(f) Miscellaneous insurance business, being insurance business not falling under any of the foregoing paragraphs (a), (b), (c), (d) or (e) of this subsection".

It is very instructive to note that this work deals directly with section 2 (a) (b) and (f) respectively.

Lagos Nigeria is the largest State in Nigeria only next to the present capital Abuja. Being the fist capital of Nigeria, Lagos state can be said to be fully developed in terms of infrastructure, businesses etcetera. Due to structural and other forms of development, landholders are especially open and prone to be adversely affected by insurable risks. It is therefore surprising and a paradox that, the citizenry and indeed most landholders are yet to embrace insurance generally and more importantly fire insurance. A handful of landholders were observed to have taken out very minimal forms of insurance policies. For an instance, third party insurance covers are very popular with regard to motor and other vehicles while fire and other insurance policies were observed to have been taken out by few holders of land resulting in high risks. This phenomenon is not limited to Lagos State but the fury of fire across Lagos State in the year 2013 leaves much to be desired. It is germane to note that there had been fire incidents within and outside Lagos State in the recent past which had left devastating consequences and ought to have served as a wakeup call for all to embrace insurance as a risk cushioning instrument. Unfortunately, most landholders had not taken out insurance policies for their land and some of those that had taken out fire insurance had not been up to date with the payment of premium. Furthermore, Government and non governmental agencies participation in the field had been very minimal. Their impact is yet to be felt.

A widely read newspaper, 'the Nation' in its publication of Thursday January $10^{\text {th }} 2013$, reported that NEMA (National Emergency Management Agency) forewarned Nigerians of likely fire outbreaks in the new year 2013, from mishandling of inflammable that could be triggered by the current weather condition (Harmattan/Dry Season) among others. This warning was obviously not heeded to as the fury of fire soon went across most states including Lagos State where very little exist in terms of insurance. Until floods swept farmlands, ravaged communities and sacked millions from their homes, the warnings by the Nigerian Meteorological Agency (NIMET) and the Environment Ministry were treated with kids cloves. As those affected by the floods are still gasping with the sour tales left on their lips, the dry season spell set in with its disaster in form of fire outbreaks. Yaushau Shuiab, the Public Relations Officer of NEMA stated in an interview that the Agency had mobilized stake holders and volunteers in the likelihood of massive fire outs breaks in markets, farmlands and forests due to indiscriminate handling of inflammable and bush burning.

On Monday the $14^{\text {th }}$ January, 2013, the Nation reported on its front page that in the last 20 hours two major fire incidents had been recorded in Lagos. Fire razed the Ebute Metta neighbourhood last night and a vessel ship carrying petroleum product exploded at the Tincanlsland Port yesterday. Furthermore, the Federal and Lagos State fire service 
agencies ascribed the surge in fire outbreaks to the weather condition. Both agencies in separate interviews, said that the dry season and the attendant harmattan wind triggered the upsurge.

The Assistant Controller, Operational Command, Lagos State, Mr. Ganiyu Olayiwole in an interview, stated that the three constituents of fire, oxygen, heat and combustible usually meet in the dry season as there is great intensity of heat during that period. He recommended proper ventilation at homes and offices as panacea. With due deference, it is obvious that the precarious state of landed properties can hardly be ameliorated or shielded from the risk of fire by mere ventilation practices. Fire insurance must be presented as a viable alternative and sure protection for land holders properties especially in this Century.

Similarly, the Lagos fire boss, Rasaq Fadipe advised that residents should always turn off all electrical appliances at home and offices when not in use and he also cautioned against bush burning. It is imperative to state that in addition to taking precautions, taking out fire and other forms of insurance policies stands out as a better protective measure that is open to a landholder in Lagos and indeed the rest of the Nigerian State against the upsurge of fire incidents. For an instance, on the gth $^{\text {th }}$ January, 2013 a story building at Umuekwo quarters in Asaba Delta state was totally destroyed by fire while a source blamed it on the illegal storage of petroleum for generating plant. Moreso, on the same day, a fuel station was burnt in Lagos Island, consuming goods and properties estimated to be worth several millions of Naira. As if this is not enough, on this same $9^{\text {th }}$ of January, 2013, the palace of the Alaafin of Oyo, Oba Lamdi Olayiwola Adeyemi in Oyo State was almost completely razed by fire. The said fire was also said to have destroyed properties worth millions of naira. The areas included the 'lle Ifa' and the 'lle Ori' which is historical sites containing artifacts, ornaments and traditional relics of the people. Also the residential apartments for the Oloris (the Obas wives) were affected. The Governor Abiola Ajimobi lamented the fire and stated "It is in our definition a disaster, it consumed virtually everything. .." Close sources from the palace administration confirmed our fears that there was no viable fire insurance for the palace. The list of infernos especially in Lagos state goes on to include the destruction of the Ebute Metta Shanties on January $8^{\text {th }}$, the Ifelaye Market on the $10^{\text {th }}$ January, Ogbomosho Tankers fire at the end of January, Jones street Lagos Inferno on the $8^{\text {th }}$ of February. The Jankara Market Lagos on January $21^{\text {st }}$, the Idi Iroko market on the $28^{\text {th }}$ of January and the MMIA in Lagos also early January 2013.

Although the focus of this paper is on 2013, it will be instructive to mention a few remarkable incidences in 2012 which would buttress that the problem of lack of adequate insurance cover especially in the area of fire incidences is enshrined and is ongoing and had not therefore started in 2013.

In other to avoid repetitions and for convenience sake, the reports of the Nation Newspaper is preferred and used in this work as to refer to the others will only multiply same or similar information. The Nation of Friday August $17^{\text {th }} 2012$, carried a report that on the $16^{\text {th }}$ August, a fire razed a soap making factory at Jakande Estate (named Nagode) situated in Okokomaiko Lagos. The Nation gathered that the fire broke out when the gas used by some workers who were constructing iron wedge, ignited a load of chemical stored up near it. As they began to explode, fire engulfed the whole factory. It is worthy to note that the soap factory was insured at its inception but the premium had not been paid up to date. It is unfortunate that the owners and share holders would not have been put through a lot of avoidable hardship had the premium been paid.

In the same vein, the Nation of Wednesday September $12^{\text {th }} 2012$ reported another incident that stands out as a reminder of the consequences and hardship caused to landholders when fire and other form of insurance is neglected. The paper stated that emotions are no doubt running high to effervescent levels over the recent decision by the ministry of Aviation to lift the suspension imposed on Dana Air. The airline was suspended in the affermath of the crash involving its aircraft at lju-Ishaga, a Lagos suburb on Sunday $3^{\text {rd }}$ June, 2012. The crash claimed 163 lives and destroyed many properties. One of the victims, Daniel Omowunmi, the owner of the storey building, warehouse and factory destroyed by the ill-fated aircraft granted on interview with some notable national daily newspapers claiming among other things that after several months of the incident, he was yet to be compensated by the airline. The paper urged the Government and the airline to minimize the agony of the bereaved and other victims by a prompt and adequate payment of compensation. It is sad to observe that the said storey building, factory and warehouse was not insured against fire or other risks.

Unarguably, it is apparent from the foregoing that the practice of taking out fire insurance among the landholders is almost non-existent. Many landholders do not trust the insurance industry to make good their promise of indemnity and a few trust in the traditional forms of social insurance schemes which had been proven to be inadequate to cater for the present risks to which landholders are exposed. Furthermore, the minimal actual practice by the insurance industry in Lagos and other States are not without serious problems. In fact, most of their methods and practices stand on a quicksand and have no backing of the law thereby adding to the precarious state of landholders' property in Lagos Nigeria. 
Section 14 (1) of the Insurance Act provided that

"Subject to subsection (4) of this section, no insurance policy or certificate of insurance shall be issued and no contract of insurance shall be entered into by any insurer without the prior approval; of the Director and no rider, clause, warranty or any endorsement whatsoever shall be attached to, printed or stamped upon any document containing any such policy, certificate of contract or deleted there from unless the form of such rider, clause, warranty or endorsement or the matter to be deleted has the prior approval of the Director".

It is observed that insurers enter into contracts of insurance and that insurance policy and certificates are freely issued without first obtaining the requisite consent of the Director. The said consent was usually sought afterwards. Section 14(3) provides that

"any insurer that issues any policy or certificate or enters into any contract otherwise than in compliance with subsection (1) of this section shall be guilty of an offence and liable on conviction to a fine of N2,000.00 only".

The proposed punishment against an offender of this section is too unrealistic in view of the seriousness of the offence. A term of imprisonment ought to have been prescribed and the fine upgraded to reflect the economic realities of our time. Same also goes for section 26 (3) which prescribed some fines against insurance agents who do not pay premiums collected by them to the insurer within 15 days after receipt thereof.

"26 (3) Any Insurance agent who contravenes subsection (2) of this section shall be guilty of an offence shall on conviction:

(a) For a first offence be liable to a fine of (100.00;

(b) For the second offence, be liable to a fine of N200; and

(c) For the third offence, be liable to a fine of $\mathrm{N500}$ and in addition his license shall be disqualified from being licensed as an insurance agent".

Furthermore, section 30 empowers the Director of insurance to investigate thoroughly agents and (or) brokers to satisfy himself as to whether any provision of the Act are complied with. The pertinent question is whether the Director and (or) his agents are performing this duty in practice. For any insurance scheme to be successful, the principles upon which the whole transaction is based ought to be fully functional and energized to achieve the desired result.

\section{Research Method}

Both primary and secondary data sources were used while purposive sampling technique was adopted. The sampling areas include the 20 main Local Government Areas in Lagos State Nigeria where a total no of 20 buildings made up of 10 commercial and 10 residential were randomly selected to represent each Local Government Area. Furthermore, for convenience, questionnaires were administered and interviews conducted strictly on the 20 building holders/ occupants. A total of one thousand (1000) questionnaires were administered in the area under research while eight hundred (800) questionnaires were retrieved as well as found useful. There were 40nos selected from each Local Government for ease of handling. The result is expected to represent a fair view of the actual situation between landholders and the practice of fire insurance in the area.

The data collected was analyzed using simple descriptive statistics and percentages.

Table 1: The 20 Local Government Areas Their Population And Questionnaires.

\begin{tabular}{|lllcc|}
\hline S/NO & Name of Ig & Population & $\begin{array}{c}\text { No of questionnaires } \\
\text { administered }\end{array}$ & $\begin{array}{c}\text { No of questionnaire } \\
\text { useful }\end{array}$ \\
\hline 1. & Alimosho & $1,277,714$ & 100 & 40 \\
2. & Ajeromi-Ifelodun & 684,105 & 60 & 40 \\
3. & Kosofe & 665,393 & 48 & 40 \\
4. & Mushin & 633,009 & 45 & 40 \\
\hline 5. & Oshodi-Bolo & 621,509 & 42 & 40 \\
6. & Ojo & 598,071 & 41 & 40 \\
\hline
\end{tabular}




\begin{tabular}{|c|c|c|c|c|}
\hline 7. & Ikorodu & 535,619 & 42 & 40 \\
\hline 8. & Surulere & 503,975 & 44 & 40 \\
\hline 9. & Agege & 459,939 & 47 & 40 \\
\hline 10. & Ifako-ljaye & 427,878 & 42 & 40 \\
\hline 11. & Shomolu & 402,673 & 60 & 40 \\
\hline 12. & Amuwo-Odofin & 318,166 & 51 & 40 \\
\hline 13. & Lagos Mainland & 317,720 & 61 & 40 \\
\hline 14. & Ikeja & 313,196 & 43 & 40 \\
\hline 15. & Eti-Osa & 287,785 & 45 & 40 \\
\hline 16. & Badagry & 241,093 & 47 & 40 \\
\hline 17. & Арара & 217,362 & 43 & 40 \\
\hline 18. & Lagos Island & 209,437 & 45 & 40 \\
\hline 19. & Epe & 181,409 & 45 & 40 \\
\hline 20. & Ibeju-Kekki & 117,481 & 50 & 40 \\
\hline \multicolumn{2}{|c|}{ Total for Lagos State } & $9,013,534$ & 1000 & 800 \\
\hline
\end{tabular}

Table 2: Form of occupation Widely Practiced in Lagos.

\begin{tabular}{|lllc|}
\hline S/NO & \multicolumn{1}{c}{ Option } & No of respondent & Percentage \% \\
\hline 1. & Owner Occupier landholder & 440 & 55 \\
2. & Tenant landholders & 100 & 12.5 \\
3. & Commercial building landholder & 260 & 32.5 \\
\hline & TOTAL & 800 & 100 \\
\hline
\end{tabular}

Table 2 shows that most of the respondents were landholders who actually own the land while very few are tenants. Most respondents are therefore persons who can offer credible information regarding fire insurance of the land they occupy.

Table 3: Level of Awareness of Fire Insurance for Landed Properties and the Government Dictate that Public Properties be Insured.

\begin{tabular}{|c|c|c|c|}
\hline S/NO & Option & No of respondent & Percentage $\%$ \\
\hline 1. & Aware of need for fire insurance & 500 & 62.5 \\
\hline 2. & $\begin{array}{l}\text { Aware of compulsory requirement of insurance for public } \\
\text { properties }\end{array}$ & 100 & 12.5 \\
\hline \multirow[t]{2}{*}{3.} & Not aware and bothered about insurance issues. & 200 & 25 \\
\hline & TOTAL & 800 & 100 \\
\hline
\end{tabular}

It is vivid that the level of awareness about fire insurance is very high among landholders, but the problems seem to be on the actual taking out of insurance policies.

Table 4: Landholders Who's Land Is Covered By Fire Insurance

\begin{tabular}{|llcc|}
\hline S/NO & \multicolumn{1}{c|}{ OPTION } & NO OF RESPONDENT & PERCENTAGE \% \\
\hline 1. & $\begin{array}{l}\text { Land covered under fire insurance with } \\
\text { premium paid to date }\end{array}$ & 240 & 30 \\
2. & $\begin{array}{l}\text { Land not covered by fire insurance } \\
\text { Not aware if landlord took out fire } \\
\text { insurance }\end{array}$ & 460 & 57.5 \\
\hline & 100 & 12.5 \\
\hline
\end{tabular}

Table 4 shows that inspite of the awareness for fire insurance, majority of the landholders are either skeptical of the scheme or have not embraced same as a viable risk bearer. 
Table 5: level of satisfaction with the present practice of insurance business in lagos.

\begin{tabular}{|c|c|c|c|}
\hline S/NO & OPTION & NO OF RESPONDENT & PERCENTAGE $\%$ \\
\hline 1. & Satisfied & 240 & 30 \\
\hline 2. & Not satisfied & 560 & 70 \\
\hline & & 800 & 100 \\
\hline
\end{tabular}

Table 5 shows a great level of dissatisfaction among landholders regarding insurance business in general. This could stem from the manner it is carried on and the fact that is it alleged that they hardly pay claims when it is due. They are said to avoid the payment on flimsy excuses.

\section{Conclusion}

There is no doubt in the fact that the insurance companies are to assume risk as one of the measures for the mitigation of losses in the society especially with regard to the rage of fire. However, lack of adequate motivation in terms of proper enlightenment and fair contractual terms as well as delay and (or) refusal to pay premium and claims are some of the factors bedeviling the practice today. In view of this landholders are dissatisfied. A successful relationship is yet achievable if the Government can adopt a more direct participatory approach with regard to matters relating to fire and indeed other forms of insurance.

The work recommends a government intervention in the insurance industry to bring a direct control of the practice operations by insurance companies. Its participation must go beyond the issuance of insurance licenses to the control of actual practice by ensuring compliance and equity. Governmental participation in the area of sole ownership of insurance companies or being Joint owners with other industrial or groups would be welcome. Furthermore laws should be made to provide mechanism for landholders to be protected from unscrupulous insurers and realistic punishments of offenders in terms of fines and imprisonment be put in place. Fire insurance should be made compulsory for landholders whether of developed plots or bare land. The rule of law must be strictly adhered to if the landholders would fully embrace insurance as an effective way of mitigating the fury of fire incidences and encourage an enduring economic and real estate development in Lagos Nigeria.

\section{References}

Irukwu J.O (1977) Insurance Management in Africa the Caton Press West Africa Ltd Ibadan Nigeria.

Mick Woodley (2009) Osborne's concise Law Dictiionary $11^{\text {th }}$ ed, Sweet \& Maxwell Pub London.

Olayonwa G.O (2000) Property Management Principles and Practices, Debo pub Co., Iwo, Nigeria

The Insurance Act, Cap 183, Laws of the Federation of Nigeria, 1990, now Laws of the Federation 2004 ed.

The Nation Newspaper publication, Friday August 17; 2012.

The Nation Newspaper Publication, Wednesday, September 12, 2012.

The Nation Newspaper Publication, Thursday, January 10, 2013.

Williamson H.R. (1988) Commercial Property Risk Management. $2^{\text {nd }}$ ed. Vol. 2, sweet \& Maxwell Pub. London.

www, nigeriapropertiesonlin.com. Jan, 2013

www.http://en.m.Wikipedia. Org/wiki. Aril 2013 